\title{
Pandangan Masyarakat tentang Keulamaan Perempuan
}

\section{Paridah Napilah $^{{ }^{*}}$, Dadang Kuswana ${ }^{2}$, Bambang Qomaruzzaman ${ }^{3}$}

1 UIN Sunan Gunung Djati Bandung, Indonesia; paridah.napilah@gmail.com

2 UIN Sunan Gunung Djati Bandung, Indonesia; dadangkuswana@uinsgd.ac.id

3 UIN Sunan Gunung Djati Bandung, Indonesia; bambang.q.anees@uinsgd.ac.id

* Correspondence

Received: 2021-06-28; Accepted: 2021-08-12; Published: 2021-08-17

\begin{abstract}
Abstrak: Penelitian ini berawal dari adanya perbedaan pandangan masyarakat di Kecamatan Sagaranten Kabupaten Sukabumi terkait dengan ulama perempuan. Hal ini berasal dari pandangan bahwa ulama itu pantasnya ditujukkan kepada laki-laki yang memiliki ilmu agama karena ulama itu pewaris para Nabi sedangkan para Nabi itu adalah laki-laki. Selain itu, perempuan itu merupakan tempatnya fitnah sehingga memiliki batasan yang ketat ketika berkecimpung di masyarakat. Penulis menggunakan metode kualitatif deskriptif dengan teknik pengumpulan data melalui observasi, wawancara mendalam dan dokumentasi. Hasil penelitian ini menunjukkan bahwa masyarakat Kecamatan Sagaranten Kabupaten Sukabumi memiliki corak pemikiran tradisional dan juga modern. Pandangan yang bercorak tradisional melihat bahwa seorang perempuan yang memiliki ilmu agama tidak diperkenankan untuk melakukan kegiatan keagamaan di masyarakat dengan jemaah yang tercampur antara laki-laki dan perempuan. Hal ini didasarkan pada bahwa perempuan tempatnya fitnah sehingga dari suara seorang perempuan dianggap sebagai aurat. Yang kedua, pandangan yang bercorak modern memandang bahwa perempuan yang memiliki ilmu agama diperbolehkan untuk berkecimpung di masyarakat sehingga tidak ada batasan selama ia mampu dan ada kesempatan.
\end{abstract}

Kata Kunci: Dakwah Islam; Islam modern; kiprah perempuan; masyarakat beragama; pandangan tradisional.

\begin{abstract}
This research started from the differences in the people's views in Sagaranten District, Sukabumi Regency related to female clerics. It stems from the idea that it is appropriate for the ulama to be addressed to men with religious knowledge because the ulama are heirs to the prophets while the prophets are men. In addition, women are a place for slander so they have strict limits when working in society. The author uses descriptive qualitative methods with data collection techniques through observation, in-depth interviews, and documentation. The results of this study indicate that the people of Sagaranten District, Sukabumi Regency have both traditional and modern patterns of thought. The conventional view sees that a woman who has religious knowledge cannot carry out religious activities in a community with a mixed congregation of men and women. It is based on women being slander so that a woman's voice is considered aurat (which must be hidden). Second, the modern view views that women who have religious knowledge can be involved in society. There are no restrictions as long as they are able and have the opportunity.
\end{abstract}

Keywords: Islamic da'wah; modern Islam; religious communities; traditional views; women's gait.

\section{Pendahuluan}

Agama Islam hadir sebagai sebuah agama yang mempunyai misi yang suci agar membebaskan dari ketertindasan kaum perempuan. Perempuan merupakan salah satu golongan masyarakat yang mendapat perhatian secara khusus supaya bisa terlepas dari ketidakadilan dan penindasan. Perlakuan yang tidak adil pada masa lampau menjadi tujuan hadirnya Islam untuk mengangkat derajat serta martabat golongan perempuan setinggi-tingginya sehingga bisa mengubah cara pandang dan cara memperlakukan perempuan lebih beradab tanpa adanya perlakuan diskriminatif yang diterima 
(Takdir, 2015). Islam mengangkat derajat seorang wanita dan memberinya kebebasan, kehormatan serta kepribadian yang independen. Bahkan tidak ditemukan ayat yang menunjukan tentang keutamaan seseorang disebabkan unsur jenis kelamin atau keturunan suku bangsa tertentu (Andika, 2018).

Perempuan digambarkan sebagai manusia yang memiliki kedudukan sangat baik pada saat Islam mulai berkembang. Terdapat beberapa yang menjadi seorang ulama Banyak di antara mereka yang menjadi ulama serta memiliki peran dibidang yang lainnya. Kualitas yang dimiliki perempuan hampir sama dengan laki-laki dalam bidang ilmu pengetahuan. Segala tentang sejarah hidupnya tertulis di beberapa buku (Farida \& Kasdi, 2018). Pada saat ini tentunya banyak tokoh ulama perempuan yang mulai bermunculan di ruang publik. Penerimaan dari masyarakat muslim terhadap tokoh ulama perempuan semakin terbuka sehingga banyak dari ulama perempuan dapat menjadi guru di madrasah, pemimpin pesantren dan juga mengisi kegiatan-kegiatan keagamaan di televise dan sebagainya (Razak \& Mundzir, 2019).

Sebagai contoh kiprah kaum perempuan dalam dakwah Islam adalah Aisyah isteri Nabi Muhammad saw yang memberikan kontribusi dalam meriwayatkan hadist sebagai bekal penting untuk menyebarkan agama Islam secara menyeluruh. Kontribusi yaang sangat cepat telah dilakukan oleh Aisyah yaitu bukti nyata akan posisi perempuan dalam berbagai aspek kehidupan, terutama dalam bidang dakwah Islam. Aisyah boleh dibilang sebagai contoh tokoh ulama perempuan di masa Nabi yang memiliki pengetahuan luas dalam bidang hadist, fiqh, sejarah, tafsir dan lain sebagainya (Takdir, 2015). Untuk itu seorang pemimpin agama yang telah ditunjuk masyarakat untuk berperan dijadikan sebagai pimpinan mereka maka sudah selayaknya ia mampu menjalankan apa saja yang dipertanggungjawabkan kepadanya (Rivai \& Bachtiar, 2013).

Berkaitan dengan masalah perempuan selalu menarik dan pantas untuk dikaji dan telah berlangsung hampir seusia dengan lahirnya kebudayaan Islam. Sampai saat ini, pandangan tentang perbedaan kaum laki-laki dan juga kaum perempuan ternyata masih menimbulkan berbagai persoalan, baik dari segi substansi kejadian bahkan persoalan peran yang ada di dalam masyarakat (Muttaqien, 2019; Umar, 2001). Dalam masyarakat peran atau kedudukan perempuan masih menjadi pokok persoalan, dimana kecendrungan bahwa aturan Islam menghambat ruang gerak kaum perempuan dalam kehidupan masyarakat. Hal ini didukung oleh pernyataan bahwa tempat terbaik bagi kaum perempuan adalah di dalam rumah, sedangkan perempuan untuk diluar rumah tidak diperbolehkan, karena dianggap akan menimbulkan kemudharatan (Arani, 2002).

Pandangan masyarakat Sagaranten ulama itu tidak hanya di tujukan kepada laki-laki juga kepada perempuan, fenomena ini jarang sekali terjadi di masyarakat lain. Selain itu di Kecamatan Sagaranten terdapat pula wanita yang memiliki ilmu keagamaan yang tinggi dan juga berkecimpung di masyarakat dan memimpin kegiatan keagamaan seperti pengajian, tahlilan, empat bulanan, mengajar di pondok pesantren dan mengajar di lembaga sekolah formal. Hal ini memberikan gambaran bahwa perempuan dalam konteks keagamaan khususunya di Kecamatan Sagaranten memiliki peran yang sangat penting karena memiliki kedudukan dan ilmu agama yang tinggi sehingga dapat berkontribusi dalam kegiatan keagamaan.

Namun dalam relitasnya di masyarakat kecamatan Sagaranten ada pula yang memiliki pandangan berbeda tentang ulama perempuan. Perbedaan itu terletak pada pandangan bahwa ulama perempuan dianggap memiliki batasan-batasan tertentu sehingga tidak diperkenankan untuk menjadi pemimpin keagamaan di masyarakat. Hal ini disebabkan karena perempuan itu tempatnya fitnah dari suaranyapun dianggap sebagai aurat.

Selain itu ada juga yang membolehkan seorang ulama perempuan melakukan kegiatan keagamaan dan berkecimpung di masyarakat sesuai dengan pandangan ibu Siti Nur Hikmah beliau sebagai penceramah dan pengajar di pondok pesantren di Kampung Gudang menjelaskan bahwa perempuan bisa disebut ulama karena didasarkan pada keterangan "Al ulama'u warasatul Anbiya" ulama merupaan pewaris para-Nabi untuk melanjutkan syi'ar-syi'ar nabi dalam menegakkan agama Allah Swt yang mengajak manusia kepada yang benar yang diridhoi Allah swt. 
Berbicara tentang ulama perempuan yang menjadi pemimpin khususnya dalam lingkup keagamaan memunculkan berbagai pandangan yang berbeda-beda. Seperti halnya Abbas Mahmud alAqqad ia sebagai seorang sarjana Islam yang tidak setuju perempuan menjadi seorang pemimpin disebabkan karena pada dasarnya antara laki-laki dan perempuan memiliki perbedaan fisik yang menjadikan prasarat manusia ketika mengemban tanggung jawab sosial. Menurut al-Aqqad mengemukakan bahwa yang berhak menjadi pemimpin yaitu berdasarkan atas kemampuan dan kesanggupan alamiah yang cenderung dimiliki kaum laki-laki dan bukan perempuan. Menurutnya perempuan bisa menjadi pemimpin hanya di ruang lingkup rumah tangga sedangkan untuk laki-laki seluas perjalanan hidup (Al-Aqqad, 1986).

Tujuan dari penelitian ini untuk mengetahui pandangan masyarakat tentang ulama perempuan di Kecamatan Sagaranten. Adapun penelitian sebelumnya berkaitan dengan penelitian yang dilakukan peneliti yakni penelitian (Isnaini, 2016) dengan judul "Ulama Perempuan dan dedikasinya dalam Pendidikan Islam telaah pemikiran Rahman El-Yunusiyah", yang menjeaskan bahwa tokoh pendidikan bagi kaum perempuan yang telah berkontribusi untuk memperjuangkan pendidikan perempuan dan mendirikan sekolah khusus mulai dari jenjang sekolah dasar hingga perguruan tinggi. Selain itu penelitian (Juraida, 2018) dengan dengan judul "Pandangan tokoh pesantren terhadap eksistensi ulama perempuan di kabupaten Aceh Barat", dijelaskan bahwa ulama dipandang dalam masyarakat Kabupaten Aceh Barat lebih cenderung sebagai panggilan kewajiban publik yang lebih cocok bagi kaum laki-laki yang sesuai dengan agama dan kepantasan adat.

Selanjutnya menurut Max Weber menjelaskan bahwa pola kepemimpinan berdasarkan pada tiga aspek pertama yaitu wewenang karismatik yang di dasarkan pada kharisma atau kemampuan khusus yang dimiliki seseorang dan melekat pada dirinya karena berdasarkan pada anugrah Tuhan yang Maha Kuasa, kharisma menjadi ciri atau bakat yang dimiliki seseorang dan berbeda dari yang lain. Ia memiliki kebijaksanaan atau kekuatan yang di unggul (Veeger, 1993).

Berbicara tentang perbedaan pandangan masyarakat terhadap ulama perempuan yang menjadi pemimpin, pandangan al-Gazali ada dua terkait dengan ulama pertama ulama dunia ulama yang memiliki orientasi keilmuan tertuju pada kenikmatan dunia yaitu untuk mencapai kedudukan dan jabatan. Kedua ulama akhirat yaitu ulama yang tidak mencari ilmu untuk harta dan selalu berhati-hati dalam memberikan fatwa (Farida \& Kasdi, 2018). Mengingat ulama merupakan ilmua, cendekiawan atau intelektual, maka tidak bisa dinafikan bahwa kehadiran ulama ditengah umat sangatlah penting. Secara teologis hal ini dibenarkan oleh sebuah hadist yang menyatakan bahwa ulama itu pewairis oara Nabi (Ulum, 2015).

Dalam pandangan Quraish Shihab, seorang ahli tafsir Indonesia menjelaskan bahwa ulama memiliki ciri seperti yang dijelaskan dalam al-quran yaitu seseorangyang memiliki pemahaman serta selalu memperhatikan kitab Tuhan yang telah terhampar di bumi. Seorang ulama sennatiasa melihat segala ciptaan Tuhan, dengan melihat kekuasan-Nya itu ia mampu memmiliki rasa takut dan menjadi seseorang yang benar-benar bertakwa. Para ulama juga memilki rasa takut kepada Allah yang mana kedudukannya sudah pada tingkat makrifat yang mendalam. Sehingga dengan ilmu yang dimilikinya menjadi pedoman untuk menjalani kehidupan dunia. Ttugas ulama yaitu mengingatkan dan memberi nasehat kepada pemerintah (umara) agar tidak menjadi pemerintah yang zhalim. Ulama memiliki kewajiban menyerukan agar umat taat kepada pemerintah selama mereka tidak berbuat zhalim. Dengan demikan, ulama menjadi penyeimbang antara posisi umaro dan umat (Ulum, 2015).

Selanjutnya Azra, menggunakan teorinya Jonathan Berkey menjelaskan terkait dengan ulama perempuan bahwa sampai saat ini setidaknya di Timur Tengah masih sangat sulit bagi kaum perempuan untuk menjadi seorang ulama. Alasannya karena peran sangat terbatas diberikan kepada perempuan, yakni cenderung hanya pada ruang domestic sphare (urusan rumah tangga), dan tidak pada public sphare yaitu urusan kemasyarakatan. Posisi perempuan yang marjinal dalam dunia keulamaan dan keilmuan harus dipahami dari berbagai faktor baik budaya, politik, ekonomi, sosial, dan bahkan agama untuk konteks Indonesia tidak jauh berbeda dengan Timur Tengah yang male-centris yang saling mempengaruhi dalam menentukan posiisi perempuan (Farida \& Kasdi, 2018; Isnaeniyah, 2017). 
Maka dalam hal ini penulis tertarik untuk meneliti tipologi pandangan masyarakat tentang ulama perempuan dan dalam penelitian ini yang menjadi fokus untuk dijadikan sumber data informasi yaitu masyarakat yang ada di lingkungan Kecamatan Sagaranten Kabupaten Sukabumi diantaranya yaitu santri, kyai, ustadazah dan masyarakat lainnya yang mampu memberikan pandangannya terkait dengan tema penelitian.

\section{Metode}

Metode penelitian yang digunakan oleh peneliti yaitu deskriptif kualitatif, dalam hal ini menjelaskan bahwa penelitian kualitatif merupakan analisis yang digunakan lebih bersifat deskriptif analitik yang berarti interpretasi terhadap isi dibuat dan disusun secara sistematis atau menyeluruh (Moleong, 2004). Pendekatan yang penulis gunakan dalam penelitian ini yaitu pendekatan sosiologis yang mana dari pendekatan ini penulis ingin mengkaji lebih dalam terkait fenomena-fenomena keagamaan yang terjadi dalam masayarakat khususnya di Kecamatan Sagaranten.

Sumber data primer yaitu melalui observasi dan wawancara secara mendalam dengan informan yang memberikan informasi terkait dengan situasi dan kondisi tema penelitian (Sugiyono, 2012). penulis menentukan informan dengan menggunakan teknik purposive sampling yaitu dengan pengambilan sample didasarkan atas tujuan tertentu yaitu orang-orang yang memiliki kriteria sebagai sample (Creswell, 2016). Informan dalam penelitian ini yaitu orang-orang yang mampu memberikan informasi terkait dengan pandangan masyarakat tentang ulama perempuan menjadi pemimpin. Maka dalam peneltiian ini tentunya yang menjadi informan yaitu: Ikbal Hidayat sebagai ketua MUI Kecamatan Sagaranten; Risnawati sebagai ketua Mualimat Kecamatan Sagaranten; Saefulloh sebagai ustadz di Kecamatan Sagaranten; Sirojuddin sebagai ustadz di Kecamatan Sagaranten; Munajah sebagai ustadzah di Kecamatan Sagaranten; Nur Hikmah sebagai ustadzah di Kecamatan Sagaranten; Sayogi sebagai ustaza di Kecamatan Sagaranten; Iat Mulyati guru dan ustazdah di Kecamatan Sagaranten; Ida sebagai ustadzah di Kecamatan Sagaranten; Faisal sebagai santri di Ponpes di Keacamatan Sagaranten; Ahmad sebagai ustadz di Kecamatan Sagaranten; Yusef sebagai ustadz di Kecamatan Sagaranten; Rojani sebagai ustadz di Kecamatan Sagarante; Soleh sebagai ustadz di Kecamatan Sagaranten; Supyan sebagai ustaz di Kecamatan Sagaranten; Zenal sebagai ustadz di Kecamatan Sagarantwn; Abdul Rozak sebagai ustadz di Kecamatan sagaranten; Hendra sebagai santri di Kecamatan Sagaranten; Mulyadi sebagai ustadz di Kecamatan Sagaranten; Maulana sebagai ustadz di Kecamatan Sagaranten. Sedangkan Data sekunder merupakan sejumlah karya tulis yang ditulis orang lain berkenaan dengan objek yang diteliti seperti buku-buku, jurnal-jurnal dan sumber lainnya yang berkaitan dengan tema penelitian (Mahmud, 2011).

Teknik keabsahan data tersebut digunakan teknik triangulasi. Dalam pandangan Sugiyono teknik triangulasi merupakan proses untuk menguji kevalidan data dengan cara memeriksa data dari beberapa teknik dan dari berbagai informasi waktu ataupun (Arikunto, 2010). Adapun teknik analisis data Dalam hal ini ada tiga jalur kegiatan yang terjadi diantaranya reduksi data, penyajian data dan verifikasi data atau membuat kesimpulan (Sugiyono, 2012).

\section{Hasil Penelitian}

\section{Pandangan Masyarakat Sagaranten Tentang Ulama Perempuan}

Adapun wanita yang menjadi pemimpin negara itu diperbolehkan karena aturan yang diambil berdasarkan undang-undang dasar. Maka dalam hal ini kepemimpinan ulama perempuan dalam ranah agama memiliki batasan-batasan yang harus dilakukan oleh semua ulama perempuan karena dalam agama aturan diambil langsung dari al-Quran dan hadist yang harus tetap menjadi pedoman dalam kehidupan supaya bisa menghindari dari hal-hal yang tidak diharapkan. Terkait tentang organisasi keagamaan ustadz Sayogi Nugraha menjelaskan bahwa tidak ikut serta dalam organisasi tersebut tetapi pemahaman mungkin lebih pada Nahdatul ulama (Sayogi Nugraha, wawancara 27 Februari 2021). 
Menurut Bapak Sayogi Nugraha beliau sebagai ustadz di Kecamatan Sagaranten menejelaskan bahwa ulama merupakan orang mengerti ilmu. Selama laki-laki maupun wanita pernah mencari atau mendalami ilmu yang berdasarkan agama. Maka dalam hal ini wanita juga bisa disebut sebagai ulama memberikan nasehat keagamaan kepada umat ke jalan kebaikan (Sayogi Nugraha, wawancara, 28 Februari 2021). Selanjutnya menurut ustadz Zenal bahwa Saat ini di kecamatan Sagaranten ulama perempuan sudah sangat banyak memberikan kontribusinya terutama didunia pendidikan agama seperti menjadi guru Paud, kemudian memimpin pengajian ibu-ibu, rajaban, tahlilah dan lain-lain Sealnjutnya menurut bapak Maulana Kontribusi yang dilakukan oleh Ustadzah di daerah Sagaranten sangat banyak kebetulan istri saya ikut kontribusi dibidang keagamaan sebagai ketua Majelis Ulama Perempuan perannya sama yaitu mengajak kepada semua kaum muslimin muslimat di manapun khususnya untuk daerah Sagaranten (Zenal, wawancara, 18 Mei 2021).

Menurut bapak Sirojuddin terkait dengan ulama perempuan memiliki batasan-batasan dan tidak sebebas seorang ulama laki-laki. Ulama perempuan memiliki kebebasan dalam melakukan kegiatan keagamaan yaitu dilingkungan perempuan saja. Sedangkan untuk kaum laki-laki boleh melakukan kegiatan nya di masyarakat bagi kaum laki-laki maupun kaum perempuan. tetapi ditempat lain banyak juga perempuan yang melakukan kegiatan keagamaan dan itu diperbolehkan karena itu masih dalam kegiatan yang wajar dilakukan perbedaan itu tidak menjadi masalah selama itu memiliki niat yang sama untuk hal kebaikan (Sirojudin, wawancara, 11 Mei 2021).

Menurut ustadz Yusuf Akbar terkait dengan ulama perempuan memiliki batasan-batasan terkait menyampaikan dakwahnya, mungkin untuk tempat yang lain diperolehkan untuk berdakwah di masyarakat luas, akan tetapi dilingkungan ini kaum wanita memiliki batasan-batasan untuk melakukan kegiatannya (Yusuf Akbar, wawancara, 19 Mei 2021). Selanjutnya menurut ustadz Zenal Terkait kedudukan antara ulama perempuan dan ulama laki-laki tidak dibedakan asalkan mereka memiliki kemampuan untuk menyampaikan ilmu keagamaannya seperti yang di contohkan oleh nabi. Walaupun ulama laki-laki dan ulama perempunan memiliki kedudukan yang sama akan tetapi jangan sampai melampaui kodratnya sebagai perempuan terutama menjaga akhlak dan auratnya terhadap laki-laki. Dalam hal kegiatan yang dilakukan ulama perempuan tidak memiliki batasan dalam artian sesuai kemampuan ilmu yang dimilikinya juga harus mengikuti tuntunan sunah yang diajarkan rosul. Seperti yang dicontohkan oleh Siti Khodijah dalam menyumbangkan hartanya demi agamanya dan Siti Aisyah dengan ketaatannya terhadap rosul sebagai suaminya (Zenal, wawancara, 18 Mei 2021).

Selanjutnya menurut bapak Maulana Kedudukan ulama laki-laki dan perempuan tidak ada bedanya, orang yang berilmu lebih tinggi derajatnya dibanding dengan orang-orang yang biasanya, di dalam al-Quran disebutakan bahwa kedudukannya dimata Allah itu sama tidak ada bedanya. Dalam Islam kegiatan peran ulama perempuan di masyarakat ada batasan-batasan tertentu bukan berarti harus dibatasi akan tetapi perempuan itu harus lebih dijaga karena memiliki pribadi yang lebih sensitif daripada laki-laki sehingga perempuan dapat diartikan dengan bahasa Arab yaitu mar'ah atau dengan kata Mir'ah atau cermin dalam artian cepat pecah, Kalau barang pecah itu biasanya harus lebih hatihati menjaganya sehingga tidak bisa seperti laki-laki yang biasanya laki-laki bebas bergerak bebas berbuat apapun karena memang seorang laki-laki itu harga dirinya dengan bekerja kalau perempuan dengan menjaga diri. Terkait dengan organisasi keagamaan yang dianut oleh masyarakat Sagaranten yaitu paham Nahdatul Ulama karena dari zaman dahulu salafi yang berkembang dan untuk Muhammadiyah sedikit (Maulana, wawancara, 17 Mei 2021).

Selanjutnya menurut ustadazah Ida ia menjelaskan bahwa sosok perempuan yang berkecimpung dimasyarakt tentunya memiliki perbedaan dengan sosok laki-laki. Terkait dengan ulama biasanya sering ditujukkan kepada laki-laki. Akan tetapi perempuan di masyarakat memiliki kontribusi dalam hal keagamaan seperti mendidik anak-anak dimasjid. Karena dengan adanya sosok seorang perempuan dalam mendidik keagamaan khususnya kepada anak-anak itu lebih mudah diterima karena perempuan lebih peka dan dari cara mendidiknyapun lebih mampu diterima oleh masyarakat khususnya anak-anak. Tetapi karena mungkin sudah membudaya dan dari dulunya memang perempuan dibatasi jadi banyak sekali hal-hal yang membuat perempuan tidak terlalu banyak bergerak di masyarakat seperti kegiatan keagamaan tahlilan atau lain sebagainya itu dilakukan 
baiknya oleh laki-laki. Tetapi bisa saja oleh perempuan asalkan jemaahnya juga perempuan karena untuk menjaga dari hal-hal yang dapat menimbulkan persoalan (Iat Mulyati, wawancara, 6 Mei 2021).

Menurut kyai Saepullah ia menjelaskan bahwa ulama bisa ditujukan kepada perempuan dan perempuan boleh melakukan kegiatan keagamaan di masyarakat dengan tidak menghilangkan kodrat kewanitaannya. Terkait dengan kedudukan perempuan dan laki-laki mungkin saja ada perbedaan akan tetapi untuk menyampaikan hukum atau yang berkaitan dengan agama itu boleh-boleh saja tetapi dengan penuh kehati-hatian (Saepuloh, wawancara 17 Mei 2021). Adapun ibu Iat Mulyati ia menjelaskan bahwa kedudukan perempuan dengan laki-laki dari sudut pandang keilmuan itu tidak ada perbedaan. Tetapi terkait dengan kata ulama memang ditujukkan kepada laki-laki dikarenakan adanya dalil yaitu "Arijalu qowwamuna alannisa" laki-laki pemimpin bagi seorang wanita. Terkait dengan perempuan yang memiliki ilmu tentunya ada batasan-batasan untuk berkiprah di masyarakat karena seorang perempuan sebenarnya memiliki tugas yang lebih penting yaitu mengurus keluarga, tidak dipersoalkan apabila perempuan melakukan kegiatan diluar rumah selama tanggung jawab yang utamanya sudah dipenuhi. Seorang perempuan yang melakukan kegiatan dimasyarkat dalam bidang agama ataupun yang lainnya tentunya harus ada ijin dari suami dan juga harus mampu menjaga diri di masyarakat, karena seorang perempuan itu rentan dengan adanya fitnah. Makanya banyak juga yang terjadi ketika seorang suami tidak mengijinkan seorang istrinya melakukan kegiatan diluar rumah (Iat Mulyati, wawancara, 6 Mei 2021).

Selanjutnya menurut ustadz Mulyadi beliau menjelaskan bahwa pada zaman Nabi kedudukan perempuan dan laki-laki tidak dibedakan karena banyak hadist-hadist yang disampaikan oleh perempuan khusunya Siti Aisyah pada zaman nabi dan ini menggambarkan tidak ada perbedaan dan kedudukan nya sama untuk laki-laki dan juga perempuan. Kelahiran Rasul untuk menjungjung tinggi martabat perempuan yang awalnya ditindas dan tidak ada artinya banyak dari golongan anak perempuan yang dibunuh karena dianggap hina, akan tetapi ketika nabi ada derajat perempuan diangkat dan ini merupakan petunjuk bahwa tidak ada perbedaan antara laki-laki dan perempuan. Namun ada baiknya golongan perempuan itu memberikan atau menyampaikan hukum di jemaah perempuan lagi, agar tidak menimbulkan fitnah. Tetapi tidak masalah juga untuk menyampaikan di masyarakat secara luas. Perempuan disamping memiliki ilmu mengamalkan ilmunya ia juga ia mampu menjalankan kewajibannya sebagai ibu rumah tangga dan itu perbedaan kedudukan seorang wanita (Mulyadi, wawancara, 5 Mei 2021).

Menurut ustadz Rojani beliau menjelaskan bahwa secara keilmuan antara laki-laki tidak ada perbedaan namun dari sudut pandang martabat keduanya memiliki perbedaan. Perbedaan itu terletak dari imam, seorang wnaita tidak bisa mengimami laki-laki. Selain dari itu perempuan boleh melakukan kegiatan keagamaan lainnya seperti mengsisi ceramah dan pemimpin kegiatan keagamaan lainnya dengan menjaga etika seperti menutup aurat dan lain-lain. Menurutnya terkait dengan kata ulama tidak bisa disematkan kepada perempuan walaupun memiliki ilmu agama dikarenakan seorang Nabipun dari golongan laki-laki (Rojani, wawancara, 16 Mei 2021). Selanjutnya menurut Bapak Ahmad beliau menjelaskan kata ulama sendiri lebih cocok disematkan kepada laki-laki karena laki-laki memiliki kekuatan yang cukup untuk melaksanakan tugas-tugas kenabian yaitu menyampaikan aturan-aturan Islam. Sedangkan untuk perempuan baiknya mengurus rumah tangga anak dan suami dan apabila ia ingin berkecimpung di masyarakat seperti memimpin acara-acara keagamaan baiknya apabila masih ada laki-laki dilakukan oleh laki-laki. Dan apabila memang laki-laki tidak ada boleh perempuan yang melakukan kegiatan keagamaa tersebut.

Selanjutnya menurut Ibu Risna antara laki-laki dan perempuan itu tidak ada perbedaan yang membedakan itu hanya ketaqwaan nya saja di hadapan Allah. Tetapi memang terkait dengan kata ulama itu lebih ditonjolkan kepada kaum laki-laki karena itu sduah membudaya dan sudah dipahami oleh masyarakat secara luas. Secara tekstual itu bisa ditujukkan kepada perempuan dan laki-laki tetapi pada konteksnya kebanyakan dikhususkan kepada laki-laki. Tetapi di Sagaranten khususnya perempuan itu lebih antusias untuk aktif di masyarakat khususnya dalam kegiatan keagamaan. Tetapi pernah juga tampil berceramah ditempat lain yang memang mungkin di tempat itu keberadaan perempuan dalam hal keagamaan kurang khususnya ceramah ataupun memang punya pandangan 
lain, ketika tampil di depan masyarakat memberikan tausiyah malah di katakan oleh seorang ulama bahwa tugas perempuan itu dirumah didapur dan dikasur tidak baik untuk melakukan kegiatan apalagi di hadapan orang banyak. Ketika ada seorang ulama yang mengatakan abhwa perempuan tidak boleh berkoprah didepan umum lalu dibicarakan juga di hadapan masyarakat tidak baik untuk dilihat dan di dengar, karena ulama itu panutan apa yang dikatakannya menjadi contoh bagi yang lain sehingga harus hati-hati dalam berbicara. Maka untuk itu antara laki-laki dan perempuan secara kodrat memang ada perbedaan akan tetapi untuk berkiprah didepan masyarakat semuanya memiliki kesamaan tidak ada perbedaan antara keduanya. Mestinya tidak adda perbedaan dan tidak harus dipersoalkan terkait wanita yang berkecimpung di masyarakat. Karena pada dasarnya semua sama derajatnya di hadapan Allah hanyak ketaqwaannya yang membedakan (Risnawati, wawancara, 17 Mei 2021).

Selanjutnya menurut ustadz Oleh ia menjelaskan bahwa ulama itu ditujukkan kepada laki-laki dan bagi perempuan yang memiliki ilmu disebut dengan ustadzah. Karena tidak ada para wali itu ditujukkan kepada perempuan dan seorang Nabipun yaitu dari golongan laki-laki. Terkait dengan ustadzah yang berkecimpung di masyarakat mereka memiliki batasan yang sangat ketat sehingga apapun yang dilakukannya baik dari suaranya harus pela-pelan tidak mengeraskan suaranya dikarenakan perempuan itu memiliki aurat. Seperti memberikan ceramah didepan umum dilarang untuk menggunakan pengeras suara terkecuali di jemaah wanita ia diperbolehkan untuk mengeraskan suaranya. Berbeda dengan laki-laki atau ulama yang memberikan ceramah itu diperbolehkan dikeduanya baik jemaah laki-laki ataupun jemaah perempuan (Soleh, wawancara, 16 Mei 2021).

Perempuan itu sangat ketat batasannya tidak boleh mengeraskan suaranya sekaligus jemaahnya perempuan itu tidak diperbolehkan untuk menggunakan pengeras suara. Maka perlu diperhatikan bahwa ketika perempuan melakukan kegiatan keagamaan harus dengan suara yang pelan-pelan tidak keras. Seperti melakukan komat dan lain sebagainya karena dikhawatirkan akan menimbulkan fitnah ketika lain muhrim mendengar suara dari wanita tersebut (Rosyad, Mubarok, Rahman, \& Huriani, 2021). Terkait dengan ulama di masyarakat memiliki dua hal pertama mufakot dan kedua ghoir mufakot yaitu harus memiliki kesabaran karena ketika berkiprah di masyarakat tentunya ada yang setuju dan tidak ada yang suka dan tidak sehingga ulama itu harus memiliki sikap lapang dada tingkat kesabaran sehingga tetap menerima anggapan yang baik dan buruk dari masyarakat. Selanjutnya terkait dengan ulama diharuskan mampu mengontrol diri melaksanakan segala bentuk perintah Allah, jangan sampai menyuruh orang lain tetapi diir sendiri tidak malaksanakannya. Seperti menyuruh melaksanakan shalat tahajud sebelum memberikan perintah kepada orang lain maka terlebih dahulu sudah melaksanakannya.

Selanjutnya menurut ustadz Supyan beliau menjelaskan bahwa kedudukan perempuan memang berbeda dengan laki-laki. Seorang perempuan harus mampu menjaga sikap dan perilakunya ketika melakukan kegiatan diluar rumahnya (Kuswana, Qomaruzzaman, \& Mahatma, 2020). Karena wanita itu memiliki batas aurat yang harus dijaga dan untuk menjaga fitnah. Sehingga perlu diperhatikan lagi ketika misalkan melakukan kegiatan keagamaan harus dengan jemaah yang sejenis atau sesama kaum wanita dan wanita tidak boleh memimpin kegiatan keagamaan seperti tahlilan dan yang lainnya selama laki-laki masih ada (Supyan, wawancara, 20 Mei 2021).

Menurut Ibu Munajah perempuan dalam hal apapun boleh-boleh saja melakukan kegiatan dan tidak ada batasannya. Perempuanpun boleh menjadi apapapun karena apapun yang dilakukan tergantung kepada apa yang diniatkan sehingga dalam hal ini tidak ada batasan. Perempuan pun sebenarnya seseorang yang memiliki kemampuan yang luar biasa dikarenakan bukan hanyak tanggung jawab nya sebagai ibu rumah tangga akan tetapi sebagai aktifitis di masyarakat (Truna, 2002; Zulaiha \& Busro, 2021). Perlu diketahui juga bahwa laki-laki dan perempuan memiliki hak yang sama tetapi memang secara hakikatnya ada perbedaan. perbedaan bukan menjadi hambatan satu sama lain harus saling mendudukung antara laki-laki dan perempuan. tetap laki-laki imam keluarga yang memimpin anggota keluarganya yang harus dihormati oleh istri dan anaknya. Terkait dengan ulama biasanya disematkan kepada kaum laki-laki hal ini disebabkan mungkin karena sudah jadi tradisi dari jaman dahulu sehingga sampai saat ini perempuan yang memiliki ilmu agama disebut dengan 
ustadzah. Tetapi mungkin di beberapa tempat barangkali ada sebutan ulama kepada perempuan hal itu tidak menjadi masalah dikarenakan asal kata ulama itu tidak menunjukkan kepada salah satu jenis kelamin (Munajah, wawancara, 4 Mei 2021).

Selanjutnya menurut Bapak Ikbal menjelaskan bahwa wanita dan laki-laki memiliki perbedaan kedudukan sesuai dengan hadist bahwa "laki-laki itu pemimpin bagi perempuan" akan tetapi saat ini ada pembahasan tentang gender maksudnya utuk menyamakan kedudukan atau keberadaan perempuan. akan tetapi menurut bapak Ikbal ia belum menyetuji perempuan itu menyamai laki-laki. Dilihat dari kata-kata imam Abu Hanifah dan Imam Syafei terkait dengan kedudukan wanita bahwa harus bisa menjaga sikap nya dari hal-hal yang dapat menimbulkan persoalan. Tetapi diihat dari sikap keibuan wanita itu seharusnya yang lebih dekat dengan masyarakat karena bisa dilihat semua yang ada ini mau yang jadi presiden atau apapun itu keluar dari ibu bukan dari bapak dan tidak ada istilahnya hari bapak (Ikbal Hidayat, wawancara, 5 Mei 2021).

Terkait dengan perempuan yang memiliki ilmu agama memang terbentur dengan tabaruznya itu. Sehingga tetap seorang ibu yang memiliki ilmu agama ini harus menjaga kesopananya yaitu menggunakan syariat Islam seperti dalam shalat yang boleh kelihatan muka dan telapak tangan. Karean perempuan itu sangat rentan dengan fitnah misalkan ada seseorang yang memiliki sakit dihatinya ketika mendengan suara wanita mungkin akan tergoda. Maka lebih tepat untuk kaum wanita itu berdakwah dilingkungan perempuan saja karena bisa membuka hijab. Terkait dengan kata ulama biasanya di Sagaranten atau di Indonesia khususnya disematkan kepada kaum laki-laki yang memiliki ilmu agama dan dari dahulu sudah seperti itu tidak ditujukkan kepada perempuan. Selain itu banyak kegiatan keagamaan yang dipimpin dan dilakukan oleh perempuan kalau melihat hukum asal itu tidak diperbolehkan akan tetapi karena kemampuan bisa saja dan boleh dilakukan apabila dari laki-laki tidak ada yang mampu.

Selanjutnya menurut ustadzah Nurhikmah beliau menjelaskan bahwa pandangan tentang ulama perempuan yang berbeda silahkan saja selama tidak menimbulkan persoalan-persoalan di masyarakat (Rosyad, 2007). Terkait dengan perbedaan itu seharusnya tidak menjadikan umat Islam terpecah belah, umat Islam harus tetap maju untuk menegakkan agama Allah swt. Menurut ustadzah Nurhikmah ia menjelaskan bahwa tidak ada batasan untuk seorang wanita dalam melakukan kegiatannya di masyarakat dalam hal agama atau sosial, selama memiliki kemampuan diperbolehkan. Untuk seorang wanita yang menjadi batasan itu tidak boleh menjadi imam sholat untuk para lelaki selebihnya diperbolehkan. Terkait dengan sebutan ulama memang seringya untuk kaum laki-laki tetapi hal ini tidak menjadi persoalan karena kewajiban laki-laki dan perempuan untuk meneggakkan agama dengan kemampuan yang dimiliki masing-masing (Nurhikmah, wawancara, 19 Januari 2021).

Menurut Saudara Faisal menjelaskan perbedaan kedudukan antara laki-laki dan perempuan bahwa perempuan memiliki batasan, walaupun gelar ulama bisa ditujukkan kepada perempuan bukan berarti perempuan boleh menjadi pemimpin suatu kaum (Rahman, 2010). Karena yang harus dijadikan sebagai pemimpin yaitu seorang laki-laki. Karena berdasarkan hadist bahwa ulama itu pewaris para Nabi sedangkan Nabi itu seorang laki-laki dan ini mengisyaratkan bahwa yang pantas menjadi pemimpin itu laki-laki. Dalam pandangna Saudara Faisal pemimpin merupakan seseorang yang mampu mengatur dan mengarahkan suatu kaum serta mampu mempertanggung jawabkan dan mengurus suatu kaum. Sehingga yang memiliki kekuatan menjadi pemimpin itu seorang laki-laki dan diharuskan untuk kaum laki-laki (Mohammad Taufiq Rahman \& Mimbar, 2018). Terkait dengan lakilaki yang harus menjadi pemimpin banyak keterangan-keteranga yang menjadikan kamu laki-laki pantas menjadi pemimpin antara lain yaitu "Warajulun ro'i fi ahlihi wahuwa mas'uluna roiyatihi" yang artinya bahwa laki-laki adalah pemimpin dan akan dipertanggungjawabkan kepemimpinannya. Maka dalam hal ini pemimpin itu untuk laki-laki sedangkan perempuan seseorang yang dimpin oleh lakilaki. Dalam rumah tangga itu yang menjadi pemimpin laki-laki dalam kegiatan agamapun baiknya laki-laki. Untuk kata ulama itu boleh ditujukkan kepada perempuan dan laki-laki karena ulama itu memiliki arti orang yang mempunyai ilmu agama dan mengamalkan ilmunya sehingga ia mampu mencapai ridho Allah swt. Menurut Al-Ghazai bahwa ulama itu orang yang alim yang mampu 
memanfaatkan ilmunya yang memiliki rasa takut kepada Allah swt. (Faisal, wawancara, 19 Januari 2021).

Menurut bapak Hendra ia menjelaskan bahwa ulama perempuan berbeda dengan ulama laki-laki. Perempuan memiliki batasan sedangkan laki-laki tidak ada batasnya. Misalkan saat memberi ceramah untuk kaum perempuan karena sangat ketat batasannya sehingga harus ada hijab supaya tidak terbuka dan tidak terlihat oleh jemaah laki-laki. Sedangkan untuk laki-laki diperbolehkan. Karena perempuan dari suaran sudah dianggap sebagai aurat, hal itu dilakukan karena supaya menjaga dari hal-hal yang dapat menimbulkan kemudhorotan seperti menimbulkan syahwat dan lain-lain. Dan jarang sekali seorang perempuan panggilannya ulama seperti contoh ketika saat pengajian biasanya panggilan untuk perempuan yang memiliki ilmu agama itu ustadzah (Hendra, wawancara, 15 Mei 2021).

Menurut ustadz Abdul Rozak ia menjelaskan bahwa bagi kaum wanita pada dasarnya memiliki perbedaan dengan laki-laki. Dalam ilmu tidak ada perbedaan tetapi dalam pengaplikasiannya ke masyarakat itulah perbedaannya. Perempuan khusus untuk kaum perempuan sedangkan laki-laki bisa untuk menyampaikan tausiyahnya kepada laki-laki dan kepada perempuan (Wibisono, 2015). Adapun perempuan yang mampu memberikan ceramahnya dimasyarkat selama niat dan caranya baik itu diperbolehkan akan tetapi alangkah baiknya tidak karena untuk menjaga timbulnya hawa nafsu dari kaum laki-laki. Tentang istilah ulama di Sagaranten saya melihat misalkan ada acara pengajian seringnya ditujukkan kepada laki-laki dan jarang sekali ditujukkan kepada perempuan, kemungkinan hal ini terjadi karena didasarkan pada pemikiran bahwa ulama itu kebanyakan dari golongan laki-laki. Pada zaman dahulu perempuan-perempuan itu sangat sedikit untuk mencari ilmu kebanyakannya kaum laki-laki sehingga tradisinya ulama itu untuk kaum laki-laki (Abdul Rojak, wawancara, 16 Mei 2021).

\section{Analisis Pandangan Masyarakat Sagaranten Tentang Ulama Perempuan}

Apabila dikaitkan dengan teori yang di gagas oleh Hiroko Horikosi bahwa ulama itu bukan hanya seseorang yang memiliki kemampuan bidang ilmu agama saja akan tetapi ia mampu membawa perubahan sosial dengan caranya sendiri. Dilihat di Kecamatan Sagaranten banyak dari tokoh ulama perempuan yang bukan saja bertugas memimpin keagamaan saja akan tetapi juga sebagai aktor penggerak dibidang sosial seperti mendirikan lembaga sekolah, mengadakan kegiatan santunan anak yatim dan lain-lain. Hal ini menggambarkan bahwa peremuan-perempuan di Kecamatan Sagaranten memiliki kemampuan bukan dalam bidang agama saja akan tetapi di bidang sosial juga.

Dilihat di Kecamatan Sagaranten banyak dari tokoh ulama perempuan yang bukan saja bertugas memimpin keagamaan saja akan tetapi juga sebagai aktor penggerak dibidang sosial seperti mendirikan lembaga sekolah, mengadakan kegiatan santunan anak yatim dan lain-lain. Hal ini menggambarkan bahwa peremuan-perempuan di Kecamatan Sagaranten memiliki kemampuan bukan dalam bidang agama saja akan tetapi di bidang sosial juga.

Masyarakat Sagaranten pada faktanya memiliki beragam pandangan keagamaan khususnya tentang ulama perempuan ada juga yang menjelaskan bahwa ulama itu pewaris para nabi sehingga yang disebut dengan ulama itu laki-laki karena para nabi merupakan seorang laki-laki (Wibisono, 2020). Perbedaan pandangan ini melahirkan corak keberagamaan masyarakat yang berbeda, ada yang beberapa tempat di Sagaranten para kaum wanita bekiprah di masyarakat seperti memimpin pengajian, tahlilah, rajaban, empat bulanan, memberikan ceramah ada juga di beberapa tempat kiprah perempuan dibatasi hanya sebagai jamaah pengajian mingguan.

beberapa masyarakat di Sagaranten bahwa ulama harus ditujukkan kepada seorang laki-laki karena memiliki beban dan tanggung jawab yang besar. Menurut Nata (Nata, 2001), pandangan masyarakat Islam yang memiliki corak tradisional menurut beberapa pandangan bisa dilihat dari ciricirinya yaitu:

a. Ekslusip tertutup yaitu tidak menerima pendapat atau pemikiran dari luar terutama dalam bidang keagamaan.

b. Memandang bahwa semua hal yang memiliki hubungan dengan agama sebagai sebuah ajaran yang harus dipertahankan. 
c. Cenderung tekstualis-literalis yaitu adanya kecendrungan memahami ayat agama secara teks tanpa melihat latar belakang serta situasi sosial menyebabkan ayat itu turun.

d. Cenderung kurang menghargai waktu.

e. Cenderung lebih mengutamakan perasaan dari pada akal pikiran.

f. Cenderung tidak mau mengikuti perubahan dengan mempertahankan apa-apa yang sudah ada sejak zaman dahulu.

Selanjutnya masyarakat Sagaranten selain memiliki corak pemikiran tradisional banyak juga yang memiliki corak pemikiran modern seperti ketika memahami seorang wanita bahwa tidak ada batasan untuk wanita melakukan kegiatan diluar rumah selama ia memiliki kemampuan khususnya dalam bidang agama bahwasanya setiap manusia baik laki-laki maupun perempuan tidak ada perbedaan kecuali iman dan takwanya.

Berbicara tentang pandangan masyarakat tentang ulama wanita yang memiliki ragam pemahaman yang berbeda hal ini didasarkan pada intrepretasi manusia itu menghasilkan kesimpulan yang berbeda-beda hal ini dipengaruhi oleh kultur, pendidikan, ekonomi dan kepentingan hidup yang ingin dicapai (Fahrurrozi, 2016). Di sini, cara berpikir keberagamaan seseorang dipengaruhi pertama bahwa setiap orang mengartikan agama sesuai dengan pengalaman keagamanya sendiri. Kedua karena dimensi kesakralannya sehingga agama sangat menarik untuk dibicarakan. Ketiga konsepsi tentang agama akan dipengaruhi oleh disiplin ilmu dan tujuan orang yang memberikan tentang keagamaan.

\section{Kesimpulan}

Istilah ulama tidak menunjukkan kepada salah satu jenis kelamin baik laki-laki ataupun perempuan. Akan tetapi secara konvensional, di Sagaranten, ulama itu sering ditujukkan kepada lakilaki yang memiliki ilmu agama dan jarang sekali disematkan pada kaum perempuan. Hal ini disebabkan karena pemahaman agama, adat istiadat dan juga pendidikan yang ditempuh sehingga menghasilkan pandangan yang berbeda, yaitu yang bercorak tradisional dan juga modern. Pemahaman agama yang bercorak tradisional memandang bahwa ulama itu khusus ditujukkan untuk laki-laki karena melihat konteks sejarah bahwa nabi itu seorang laki-laki, akan tetapi dilihat juga dari kedudukan perempuan bahwasanya seorang perempuan memiliki batasan-batasan yang ketat sehingga untuk melakukan kegiatan di masyarakat harus tertutup dan tidak boleh mengeraskan suaranya disebabkan karena kaum perempuan tempatnya fitnah dari suara seorang wanita itu aurat.

Adapun masyarakat yang memiliki pandangan bercorak modern menjelaskan bahwa ulama sebagai pewaris para nabi yang tugasnya menjalankan tugas-tugas kenabian mensyiarkan ajaran agama Islam baik laki-laki maupun perempuan. Dalam hal ini dapat dipahami bahwa siapapun boleh melakukan dakwah, mensyiarkan agama dengan kapasitas keilmuan yang dimilikinya serta tidak melanggar etika dalam agama. Bagi kaum perempuan memang ada batasannya yaitu menutupi aurat yang boleh terlihat hanya muka dan telapak kaki dan diperbolehkan melakukan kegiatan keagamaan di masyarakat selagi ia mampu dan memiliki ilmu untuk ia sampaikan kepada masyarakat. Walaupun demikian, secara keseluruhan, masyarakat mempunyai pemikiran bahwa laki-laki dan perempuan memiliki kesamaan kedudukan di hadapan Allah dan tidak ada perbedaan kecuali yang membedakan iman dan takwanya. Terkait tentang ulama perempuan yang memiliki ilmu agama diperbolehkan untuk berdakwah, memimpin kegiatan keagamaan lainnya dengan syarat tetap menjaga marwah seorang perempuan.

\section{Referensi}

Al-Aqqad, A. M. (1986). Filsafat al-Qur'an: Filsafat. In Spiritual dan Sosial dalam Isyarat al-Qur'an,. Jakarta: Pustaka Firdaus.

Andika, M. A. (2018). Wanita Shalat Berjamaah di Mesjid (Kajian Teori Double Movement terhadap Alquran Ayat 33 Surah al-Ahzab dan Nas-nas Terkait). UIN Ar-Raniry Banda Aceh.

Arani, A. (2002). Tubuh, Seksualitas, dan Kedaulatan Perempuan. Yogyakarta: LKiS.

Arikunto, S. (2010). Prosedur penelitian: suatu pendekatan praktik. Ed. Rev. Jakarta: PT Rineka Cipta. 
Creswell. (2016). Penelitian Kualitatif dan Desain Riset: Memilih di antara Lima Pendekatan. Yogyakarta: Pustaka Pelajar.

Fahrurrozi, F. (2016). Ekspresi Keberagamaan Masyarakat Islam Indonesia: mozaik Multikulturalisme Indonesia. Toleransi: Media Ilmiah Komunikasi Umat Beragama, 7(1), 15-34.

Farida, U., \& Kasdi, A. (2018). The 2017 KUPI Congress and Indonesian Female ‘Ulama. Journal of Indonesian Islam, 12(2), 2-135.

Isnaeniyah, E. (2017). Partisipasi Politik Perempuan Islam Indonesia Dalam Tradisi “Nu”. Religious: Jurnal Studi Agama-Agama Dan Lintas Budaya, 1(2), 154. https://doi.org/10.15575/rjsalb.v1i2.1393

Isnaini, R. L. (2016). Ulama Perempuan dan Dedikasinya dalam Pendidikan Islam (Telaah Pemikiran Rahmah ElYunusiyah). Jurnal Pendidikan Agama Islam, 4(1), 2-16.

Juraida, I. (2018). Pandangan Tokoh Pesantren Terhadap Eksistensi Ulama Perempuan di Kabupaten Aceh Barat. Community: Pengawas Dinamika Sosial, 2(3), 332-341.

Kuswana, D., Qomaruzzaman, B., \& Mahatma, M. (2020). Agama dan wabah: Tanggapan ulama Jawa Barat atas Covid19 tahun 2020. UIN Sunan Gunung Djati Bandung.

Mahmud. (2011). Metode Penelitian Pendidikan. Bandung: Pustaka Setia.

Moleong, L. (2004). Metodologi Penelitian Kualitatif. Bandung: Remaja Rosdakarya.

Muttaqien, Z. (2019). Peran Perempuan dalam Tradisi Sunda Wiwitan. Khazanah Theologia, 1(1), $23-39$. https://doi.org/10.15575/kt.v1i1.7123

Nata, A. (2001). Peta Keragaman Pemikiran Islam di Indonesia, Jakarta: PT. Jakarta: Raja Grafindo Persada.

Rahman, M Taufiq. (2010). Pluralisme Politik. WAWASAN: Jurnal Ilmiah Agama Dan Sosial Budaya, 34(1), 1-13.

Rahman, Mohammad Taufiq, \& Mimbar, A. S. (2018). Konsep politik Islam kultural perspektif Nurcholish Madjid. FIKRI: Jurnal Kajian Agama, Sosial Dan Budaya, 3(2), 385-400.

Razak, Y., \& Mundzir, I. (2019). Otoritas Agama Ulama Perempuan: Relevansi Pemikiran Nyai Masriyah Amva Terhadap Kesetaraan Gender Dan Pluralisme. PALASTREN Jurnal Studi Gender, 12(2), 397-430.

Rivai, V., \& Bachtiar, B. R. A. (2013). Pemimpin dan Kepemimpinan dalam organisasi. Jakarta: PT Raja Grafindo Persada.

Rosyad, R. (2007). A quest for true Islam: A study of the Islamic resurgence movement among the youth in Bandung, Indonesia. Australia: ANU Press.

Rosyad, R., Mubarok, M. F., Rahman, M. T., \& Huriani, Y. (2021). Toleransi Beragama dan Harmonisasi Sosial. Bandung: Digital Library UIN Sunan Gunung Djati Bandung.

Sugiyono. (2012). Metode Penelitian Kuantitatif, Kualitatif dan RED. Bandung: Alfabeta.

Takdir, M. (2015). Kiprah Ulama Perempuan Nyai Hj. Makkiyah As' ad dalam Membentengi Moralitas Umat di Pamekasan Madura. 'Anil Islam: Jurnal Kebudayaan Dan Ilmu Keislaman, 8(1), 72-97.

Truna, D. S. (2002). Islam dan Politik Orde Baru di Indonesia (1966-1990). In D. S. Truna (Ed.), Pranata Islam di Indonesia. Jakarta: Logos Wacana Ilmu.

Ulum, B. (2015). Ulama dan politik: nalar politik kebangsaan Majelis Ulama Indonesia (MUI). Yogyakarta: Pustaka Pelajar.

Umar, N. (2001). Argumentasi Kesetaraan Jender Perspektif al-Qur'an. Jakarta: Paramadina.

Veeger, K. J. (1993). Realitas Sosial, Refleksi Filsafat Sosial atas Hubungan Individu-Masyarakat. In Cakrawala Sejarah Sosiologi. Jakarta: PT Gramedia Pustaka Utama.

Wibisono, M. Y. (2015). Agama, kekerasan dan pluralisme dalam Islam. Kalam, 9(2), 187-214.

Wibisono, M. Y. (2020). Sosiologi Agama. Prodi P2 Studi Agama-Agama UIN Sunan Gunung Djati Bandung.

Zulaiha, E., \& Busro, B. (2021). Tradisi Bahts Al-Masail Nahdhatul Ulama (NU): Pematangan Pemikiran Fikih Adil Gender Husein Muhammad. Musãwa Jurnal Studi Gender Dan Islam, 19(2), 205-218.

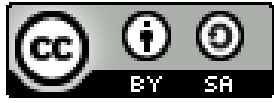

(C) 2021 by the author. Submitted for possible open access publication under the terms and conditions of the Creative Commons Attribution (CC BY SA) license (https://creativecommons.org/licenses/by-sa/3.0/). 
Halaman ini sengaja dikosongkan 